\title{
Analysis of the Lipolytic Potential of Filamentous Fungi Isolated from Some Plants and Soil Samples in Minas Gerais, Brazil
}

\author{
Paula V. D. Spencer'1, Tatiana P. Costa', Mirian J. Souza1, Nísia A. V. D. Pinto², David L. Nelson³, \\ Vivian M. Benassi ${ }^{4}$ \\ ${ }^{1}$ Universidade Federal dos Vales do Jequitinhonha e Mucuri (UFVJM), Campus JK, Diamantina, Brasil \\ ${ }^{2}$ Faculdade de Ciências Biológicas e da Saúde, Universidade Federal dos Vales do Jequitinhonha e Mucuri (UFVJM), Campus JK, \\ Diamantina, Brasil \\ ${ }^{3}$ Programa de Pós-Graduação em Biocombustíveis, Universidade Federal dos Vales do Jequitinhonha e Mucuri (UFVJM), Campus \\ JK, Diamantina, Brasil \\ ${ }^{4}$ Instituto de Ciência e Tecnologia, Universidade Federal dos Vales do Jequitinhonha e Mucuri (UFVJM), Campus JK, \\ Diamantina, Brasil \\ Email: *vivian.benassi@ufvjm.edu.br
}

How to cite this paper: Spencer, P.V.D. Costa, T.P., Souza, M.J., Pinto, N.A.V.D., Nelson, D.L. and Benassi, V.M. (2020) Analysis of the Lipolytic Potential of Filamentous Fungi Isolated from Some Plants and Soil Samples in Minas Gerais, Brazil. Advances in Bioscience and Biotechnology, 11, 475-487.

https://doi.org/10.4236/abb.2020.1111032

Received: October 9, 2020

Accepted: November 27, 2020

Published: November 30, 2020

Copyright $\odot 2020$ by author(s) and Scientific Research Publishing Inc. This work is licensed under the Creative Commons Attribution International License (CC BY 4.0).

http://creativecommons.org/licenses/by/4.0/

\section{(c) (i) Open Access}

\begin{abstract}
Microorganisms have the ability to produce several metabolites, which are widely used in biotechnological processes, including the biological catalysts called enzymes. Among these enzymes, lipases are favored because they perform various catalytic reactions such as hydrolysis, esterification, interesterification and transesterification. This work sought to isolate filamentous fungi from samples collected in Diamantina, Minas Gerais, Brazil, analyze their macroscopic morphological characteristics, determine the effect of temperature on their growth, and verify which organisms are potential lipase producers. From four collection sites, nine fungi were isolated from the leaves and soil of the jabuticaba (Plinia cauliflora) tree and three fungi from the Andu bean leaves (Cajanus cajan). The macroscopic morphological characteristics of the microorganisms were analyzed. For thermophilic analysis, the twelve isolated fungi and eight obtained from the laboratory bank were cultivated in a solid Potato-Dextrose-Agar medium from $30^{\circ} \mathrm{C}$ to $50^{\circ} \mathrm{C}$, with intervals of $5^{\circ} \mathrm{C}$. The growth rate per hour after 48 hours of development was calculated. For the selection of filamentous lipase-producing fungi, the 20 fungi were cultivated in solid $\mathrm{BDA}$ medium at $30^{\circ} \mathrm{C}$ for 96 hours, and the enzyme index was calculated. It was found that, of the 20 microorganisms, 95\% developed at $30^{\circ} \mathrm{C}$, and the highest growth rates were those of fungi 3.2TA, PJ8 and PJ7. At $35^{\circ} \mathrm{C}, 70 \%$ of the fungi developed, and the highest growth rates were those of fungi 3.2TA, MB2.2 and $\mathrm{P} 3$. At $40^{\circ} \mathrm{C}, 40 \%$ of the fungi developed, and the
\end{abstract}


highest growth rates were those of fungi $3.2 \mathrm{TA}, \mathrm{PJ} 6$ and PJ8. At $45^{\circ} \mathrm{C}$, only the PJ6 and PJ12 fungi grew, and no organism grew at $50^{\circ} \mathrm{C}$. In the screening for lipase production, the largest growth halo was observed for the $3.2 \mathrm{TA}$ fungus from the bank.

\section{Keywords}

Enzymes, Bioprospecting, Biotechnology

\section{Introduction}

In the last decades, a great effort has been made in search of alternatives to fossil fuels because it is a finite fuel and because of the pollution caused by those fuels [1]. Among the biofuel possibilities, we can mention biodiesel, which consists of methyl esters of long-chain fatty acids [2].

Various microbial enzymes are already applied in many segments of the industry; microbial lipase has already been used in the detergent industry, biofuel production and industrial effluent bioremediation/treatment because of the hydrolysis, esterification, interesterification and transesterification reactions that they can catalyze [3]-[8].

The use of microorganisms for the production of lipase is advantageous because most of them are capable of producing this biocatalyst at a high rate and relatively low cost. The global market for industrial enzymes reached US\$ 5.5 billion in 2018, and it is estimated that this value will reach US\$ 7.0 billion by 2023 , with a compound annual growth rate (CAGR) of $4.9 \%$ in the $2018-2023$ period [9].

However, to obtain enzymes with greater catalytic power, and lower the cost of enzyme production, there is a need for research that uses microorganisms isolated from new environments, as well as the use of agro-industrial residues in the composition of the media to obtain lipases with characteristics appropriate for a specific application.

The production of biodiesel is generally achieved by means of transesterification of animal or vegetable oils with methanol, using alkaline, acid or enzymatic catalysts. In the transesterification reactions using basic catalysis, alkali metal hydroxides such as potassium hydroxide and sodium hydroxide are used, with which better yields and selectivity are observed. Basic non-ionic catalysts are also used, as they have the advantage of not forming soap and other undesirable products [10] [11] [12].

In acid catalysis using a strong acid, such as sulfuric acid or hydrochloric acid, the reaction is rapid and the degree of conversion is high. However, it has several disadvantages, such as the occurrence of side reactions, corrosion of the equipment and difficult separation of the catalyst from the liquid reaction mixture [13]. 
Because the catalytic activity of a base is superior to that of an acid and acid catalysts are more corrosive, basic catalysis is preferred over acid catalysis, which is why it is most often used commercially. Although this reaction is generally performed with homogeneous catalysts, heterogeneous catalysts have advantages over homogeneous ones, both economically and environmentally [14] [15].

Regarding enzymatic catalysis, lipases (triacylglycerol hydrolases EC 3.1.1.3) stand out for being more selective and with higher yields; free fatty acids are converted into biodiesel at low reaction temperatures. The reaction conditions are milder, the enzymes are easy to separate from the reaction products, the reactions are environmentally sustainable, higher quality biodiesel and glycerol can be obtained, with lower procedural costs in the purification stages, and the enzyme can be used in homogeneous or heterogeneous catalysis. The disadvantages are the high cost of the enzymes, and the enzyme is normally inhibited in the presence of methanol/water mixtures, which requires the addition of co-solvents, thus making the process more expensive [16].

This work aimed to analyze the lipolytic potential of filamentous fungi isolated from plants and soil samples in Diamantina, Minas Gerais, analyzing macroscopic morphological characteristics of some isolated filamentous fungi, the effect of temperature on the growth of these microorganisms and verifying which are lipase producers.

\section{Material and Methods}

This work was accomplished at the Laboratory of Biomass and Technology of the Cerrado, Federal University of the Jequitinhonha and Mucuri Valleys (UFVJM) JK campus, Diamantina, Minas Gerais, Brazil.

\subsection{Microorganisms under Study}

Twenty filamentous fungi were analyzed, of which eight microorganisms identified as P3; C435; EA3.3.2 and EA1.2.1; 3.2TA; MB1.1 and MB2.2 and M1.7.1 were selected at random from several microorganisms already existing in the laboratory, the result of isolation from other studies (Table 1). Twelve filamentous fungi were isolated from samples collected by the authors [17]-[22].

The twelve filamentous fungi were isolated from samples collected aseptically in the city of Diamantina, Minas Gerais, Brazil. The materials collected were swine lard (sample 1), leaves and soil from the foot of a jabuticaba (Plinia cauliflora) tree (sample 2), Andu bean leaves (Cajanus cajan) (sample 3), and coffee grounds (sample 4). The samples were stored in glass bottles sealed by hydrophobic cotton, previously autoclaved at $120^{\circ} \mathrm{C}$ and $1.5 \mathrm{~atm}$ for 30 minutes.

The materials were transported in a sterile manner to the laboratory, where each sample was placed in a Petri dish containing 15 to $20 \mathrm{~mL}$ of $4 \%(\mathrm{w} / \mathrm{v})$ solid sterile Quaker ${ }^{\oplus}$ culture medium and $2 \%(\mathrm{~m} / \mathrm{v})$ Bacterial Agar, with the aid of autoclaved tweezers, and the microorganisms present in the samples were allowed to develop [23]. The plates containing the material were placed in a bacteriological 
Table 1. Location and sample from which the filamentous fungi selected from the laboratory were isolated.

\begin{tabular}{ccc}
\hline Filamentous fungus & Source & City where collected \\
\hline P3 & Coconut shell & Serranópolis de Minas, MG \\
C435 & Piece of denim in decomposition & $\begin{array}{c}\text { Garbage deposit at the UFVJM, } \\
\text { Diamantina, MG }\end{array}$ \\
EA3.3.2 & Seeds & Garbage deposit at the UFVJM, \\
Siamantina, MG & Diam cane bagasse & Northern region, MG \\
MB1.1 E MB2.2 & Water from the Rio Doce & Regência District, ES \\
& Leaf in decomposition & Garbage deposit at the UFVJM, \\
EA1.2.1 & Diamantina, MG \\
& Tree bark & Janaúba, MG \\
M1.7.1 & &
\end{tabular}

oven at $30^{\circ} \mathrm{C}$ for four days. The growth of new microorganisms was analyzed every 24 hours, and as the specimens grew, point isolation was performed in the center of a new culture plate containing the same medium at $30^{\circ} \mathrm{C}$.

The macroscopic morphological characteristics of the twelve isolated fungi and the already isolated filamentous fungi from the laboratory were analyzed as to the color of the colonies, aspect, topography, edge, surface, texture, size and the presence or absence of pigmentation [24].

\subsection{Maintenance of Filamentous Fungi}

The strains were stored on Dinâmica ${ }^{\circledR}$ silica gel, according to the method described by Michelin (2009), where a spore suspension was prepared from $2 \mathrm{~mL}$ of powdered milk (200 g.L $\mathrm{L}^{-1}$ of autoclaved distilled water). Approximately $1 \mathrm{~mL}$ of this suspension was added to test tubes containing $7 \mathrm{~g}$ of silica gel and stirred. These tubes were sealed and stored at $4^{\circ} \mathrm{C}$ [25]. The filamentous fungi were cultured in $15 \mathrm{~cm} \times 5 \mathrm{~cm}$ test tubes containing a solid $4 \%(\mathrm{~m} / \mathrm{v})$ Quaker ${ }^{\oplus}$ medium and 2\% Bacteriological Agar (w/v) [23]. The culture media were kept in a bacteriological incubator at $30^{\circ} \mathrm{C}$, and, after growth, stored in a refrigerator at $4^{\circ} \mathrm{C}$.

\subsection{Effect of Temperature on the Growth of Filamentous Fungi}

The determination of the rate of growth of fungi with respect to temperature was performed in a solid medium using Prodimol $^{\oplus}$ Potato-Dextrose-Agar (BDA) culture medium for 48 hours at temperatures that varied from $30^{\circ} \mathrm{C}$ to $50^{\circ} \mathrm{C}$, with intervals of $5^{\circ} \mathrm{C}$. The fungal growth radius was measured, and the growth rate in centimeters per hour $\left(\mathrm{cm} \cdot \mathrm{h}^{-1}\right)$ was calculated.

\subsection{Screening of Filamentous Fungi Producing Lipases}

The selection of filamentous lipase-producing fungi utilized the method de- 
scribed by Hankin \& Anagnostakis (1975). All the fungi were spiked punctually in the center of the Petri dish in previously sterilized solid culture medium for lipase containing Potato-Dextrose-Agar (BDA) $\left(20 \mathrm{~g} \cdot \mathrm{L}^{-1}\right)$, peptone $\left(10 \mathrm{~g} \cdot \mathrm{L}^{-1}\right)$, sodium chloride $\left(5 \mathrm{~g} \cdot \mathrm{L}^{-1}\right)$, calcium chloride $\left(2 \mathrm{~g} \cdot \mathrm{L}^{-1}\right)$ and Tween $80\left(10 \mathrm{~mL} \cdot \mathrm{L}^{-1}\right)$ and incubated in a bacteriological incubator at $30^{\circ} \mathrm{C}$ for four days.

The growth radius $(\mathrm{cm})$ of the colony was measured, and the fatty acids released by Tween 80 hydrolysis were identified using $2 \mathrm{~mL}$ of the developing solution (0.1 $\mathrm{M} \mathrm{NaOH}$ and $2 \%$ phenolphthalein). By measuring the enzymatic halo $(\mathrm{cm})$, the ratio of fungal growth to enzyme production was determined by dividing one parameter by the other.

\subsection{Reproducibility and Statistical Analysis}

All the experiments were performed in triplicate, and the means of the results and standard deviation were determined. The ANOVA and Tukey tests were applied for the statistical analyses using the Statistica TM 6.0 software (Statsoft, Inc). The correlations between the analytical determinations were performed at the $5 \%$ significance level $(\mathrm{p}<0.05)$.

\section{Results and Discussion}

\subsection{Isolation of Filamentous Fungi and Analysis of Macroscopic Morphological Characteristics of Microorganisms}

Of the twelve filamentous fungi, those designated as PJ1, PJ2, PJ3, PJ4, PJ5, PJ6, PJ7, PJ8 and PJ12 were isolated from the leaves and soil of a jabuticaba (Plinia cauliflora) tree (sample 2), whereas PF9, PF10 and PF11 were isolated from Andu bean leaves (Cajanus cajan) (sample 3), as is shown in Figure 1. No filamentous fungi were isolated from the samples of lard and coffee grounds.

(a)

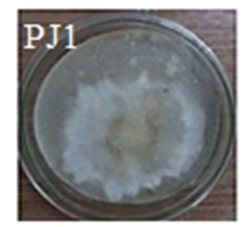

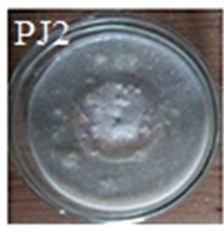

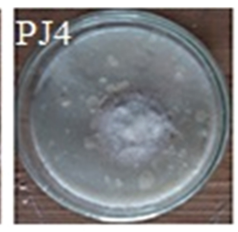

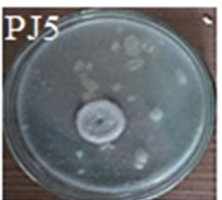
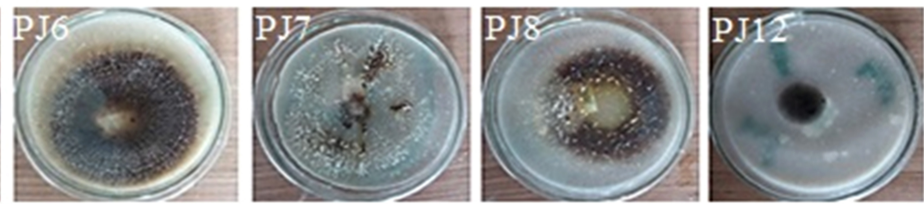

(b)
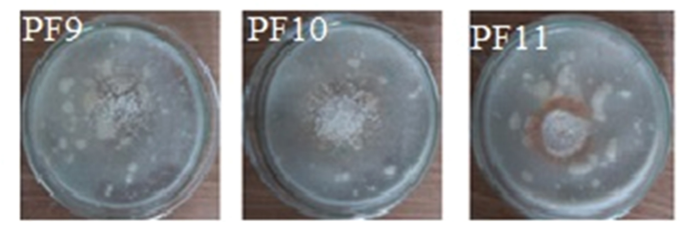

Figure 1. Representative images of isolated filamentous fungi. (a) Fungi isolated from the leaves and soil of the jabuticaba (Plinia cauliflora) tree and (b) Fungi isolated from the leaves of Andu beans (Cajanus cajan). 
After the isolation of the microorganisms, the macroscopic morphological characteristics of the isolates were determined. With regard to color, $67 \%$ presented a white color (PJ1, PJ2, PJ3, PJ4, PJ5, PF9, PF10 and PF11); the other fungi possessed brown (PJ6), brown and white (PJ7), brown and green (PJ8) and black (PJ12) colors (Table 2).

All the isolated fungi had a dry appearance. Regarding the topography, 50\% of the fungi possessed a flat topography (PJ1, PJ3, PF9, PF10, PF11 and PJ12), 25\%. a pleated topography (PJ6, PJ7 and PJ8), 17\%, a convex topography (PJ2 and PJ4 ) and 8\%, an umbilicated topography (PJ5). Regarding the border, $58 \%$ had a regular border (PJ2, PJ3, PJ4, PJ5, PJ6, PF11 and PJ12), and 42\% had an irregular border (PJ1, PJ7, PJ8, PF9 and PF10) (Table 2).

As for the surface, $75 \%$ of the isolated fungi had a smooth surface (PJ1, PJ2, PJ3, PJ4, PJ5, PF9, PF10, PF11 and PJ12), 17\%, a cracked surface (PJ2, PJ6 and PJ8) and $8 \%$, a rough surface (PJ7). Regarding the texture, $58 \%$ of the filamentous fungi possessed a cottony texture (PJ1, PJ2, PJ3, PJ4, PJ5, PJ8 and PF10), $25 \%$ had a suede texture (R6, R8 and R11), and the others had velvety (R9), granular (R7) and powdery (R12) textures (Table 2). Of the isolated fungi, $42 \%$ were of medium size (PJ2, PJ3, PJ4, PF9 and PF10), 33\%, large size (PJ1, PJ6, PJ7 and PJ8) and 25\%, tiny (PJ5, PF11 and PJ12). The PJ2, PJ3, PJ4, PJ5 and PF11 fungi possessed pink and peach pigmentations (Table 2).

In the work of Zipperer and collaborators four fungi were isolated from the soil where grape vines were planted in the city of Videir, SC, Brazil. These fungi were grown in $\mathrm{BDA}$ medium, where their macroscopic morphological characteristics were analyzed. A white color, smooth surface and cottony texture were observed [26].

Table 2. Macroscopic characteristics of isolated filamentous fungi.

\begin{tabular}{ccccccccc}
\hline Fungus & Color & Aspect & Topography & Border & Surface & Texture & Size & Pigmentation \\
\hline PJ1 & White & Dry & Flat & I & Smooth & Cottony & Large & - \\
PJ2 & White & Dry & Convex & R & Smooth & Cottony & Medium & $+($ pink) \\
PJ3 & White & Dry & Flat & R & Smooth & Cottony & Medium $+($ peach) \\
PJ4 & White & Dry & Convex & R & Smooth & Cottony & Medium $+($ pink) \\
PJ5 & White & Dry & Umbilicated & R & Smooth & Cottony & Punctual $+($ peach) \\
PJ6 & Brown & Dry & Pleated & R & Fissured & Suede & Large & - \\
P7 & Brown and white & Dry & Pleated & I & Rough & Grainy & Large & - \\
PJ 8 & Brown and green & Dry & Pleated & I & Fissured & Suede & Large & - \\
PF9 & White & Dry & Flat & I & Smooth & Velvety & Medium & - \\
PF10 & White & Dry & Flat & I & Smooth & Cottony & Medium & - \\
PF11 & White & Dry & Flat & R & Smooth & Suede & Tiny & $+($ (pink) \\
PJ12 & Black & Dry & Flat & R & Smooth & Powdery & Tiny & - \\
\hline
\end{tabular}

$\mathrm{R}$, regular and I, irregular; - no pigmentation; + presence of pigmentation. 
In the study by Souza and collaborators twenty-one fungi from tree bark, six from fruit bark and two from decomposing leaves were isolated in the city of Janaúba-MG, in BDA medium, the macroscopic morphological characteristics of these were analyzed. isolated and it was found that colony colors varied between shades of green, black, white and blue, some with pigmentation secretion with characteristics similar to those isolated by the author and all microorganisms had a smooth background, with the exception of one similar to the work carried out by the author where most of the isolated fungi also presented a smooth bottom [27].

\subsection{Effect of Temperature on the Growth of Filamentous Fungi}

When analyzing the growth of filamentous fungi at different temperatures in BDA culture medium, $95 \%$ of the fungi developed at $30^{\circ} \mathrm{C}$; only the PF9 fungus did not develop. This temperature is that at which the highest growth rates of the identified filamentous fungi such as 3.2TA $\left(0.088 \mathrm{~cm} \cdot \mathrm{h}^{-1}\right)$, PJ8 and PJ7 $(0.070$ $\left.\mathrm{cm} \cdot \mathrm{h}^{-1}\right)$; PJ6 $\left(0.068 \mathrm{~cm} \cdot \mathrm{h}^{-1}\right)$; MB2.2 $\left(0.055 \mathrm{~cm} \cdot \mathrm{h}^{-1}\right)$ and P3 $\left(0.032 \mathrm{~cm} \cdot \mathrm{h}^{-1}\right)$ were observed. The microorganisms for which the greatest growth rate was observed at this temperature were $3.2 \mathrm{TA}, \mathrm{PJ} 8$ and PJ7, with an average of $0.076 \mathrm{~cm} \cdot \mathrm{h}^{-1}$ (Figure 2).

At $35^{\circ} \mathrm{C}, 70 \%$ of the fungi developed. The fungi that obtained the highest growth rates were those identified as $3.2 \mathrm{TA}\left(0.128 \mathrm{~cm} \cdot \mathrm{h}^{-1}\right)$, MB2.2 $(0.113$ $\left.\mathrm{cm} \cdot \mathrm{h}^{-1}\right)$, P3 $\left(0.089 \mathrm{~cm} \cdot \mathrm{h}^{-1}\right)$ and PJ6 $\left(0.074 \mathrm{~cm} \cdot \mathrm{h}^{-1}\right)$. The fungi PJ1, PJ2, PJ3, PJ5, PF9 and PF10 did not develop at this temperature (Figure 2).

According to the literature, there are few filamentous fungi that can grow at temperatures above $40^{\circ} \mathrm{C}$. In the current study, $40 \%$ of the fungi developed at this temperature, and the samples that had the highest growth rates were 3.2TA

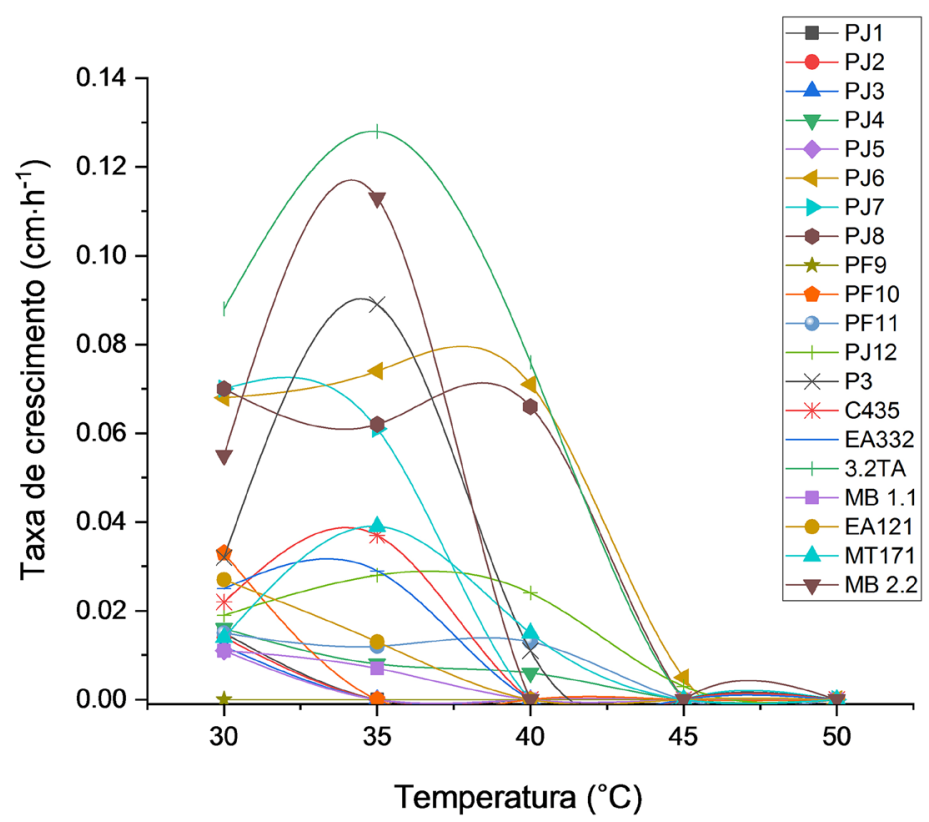

Figure 2. Fungal growth rates (cm/hour) of filamentous fungi in BDA medium. 
(0.076 $\left.\mathrm{cm} \cdot \mathrm{h}^{-1}\right)$, PJ6 $\left(0.071 \mathrm{~cm} \cdot \mathrm{h}^{-1}\right)$; PJ8 $\left(0.066 \mathrm{~cm} \cdot \mathrm{h}^{-1}\right)$; PJ12 $\left(0.024 \mathrm{~cm} \cdot \mathrm{h}^{-1}\right)$; MT171 $\left(0.015 \mathrm{~cm} \cdot \mathrm{h}^{-1}\right)$, PF11 $\left(0.013 \mathrm{~cm} \cdot \mathrm{h}^{-1}\right)$ and P3 $\left(0.011 \mathrm{~cm} \cdot \mathrm{h}^{-1}\right)$. Only the fungi PJ6 $\left(0.005 \mathrm{~cm} \cdot \mathrm{h}^{-1}\right)$ and PJ12 $\left(0.003 \mathrm{~cm} \cdot \mathrm{h}^{-1}\right)$ grew at $45^{\circ} \mathrm{C}$, and no organism developed at $50^{\circ} \mathrm{C}$ (Figure 2).

Organisms can be classified according to the ideal growth temperature and are divided into three classes, psychrophils (temperatures below $20^{\circ} \mathrm{C}$ ), mesophiles (between $25^{\circ} \mathrm{C}$ and $40^{\circ} \mathrm{C}$ ) and thermophiles (temperatures above $40^{\circ} \mathrm{C}$ ). Those classified as mesophiles form involve most microorganisms. Although they exhibit excellent growth at moderate temperatures, some of them can grow at higher temperatures, called thermotolerants [28].

Studies similar to the author's have been reported in the literature, in the analysis of growth at different temperatures, carried out by Souza in a BDA medium of $35^{\circ} \mathrm{C}$ to $50^{\circ} \mathrm{C}$, varying every $5^{\circ} \mathrm{C}$, it was concluded that all isolated microorganisms are mesophiles because they all grew at $35^{\circ} \mathrm{C}$. Thirteen fungi developed at $40^{\circ} \mathrm{C}$, seven grew at $45^{\circ} \mathrm{C}$ and three fungi developed at $50^{\circ} \mathrm{C}$, which did not occur in the author's analyzes where no fungus developed at $50^{\circ} \mathrm{C}$ [27]. Similar results have also been reported in the literature [29].

\subsection{Analysis of the Lipolytic Potential of Filamentous Fungi}

Among the isolated fungi, those identified as PJ7 and PF9 did not grow in the solid culture medium for lipases, whereas the largest halos for fungal growth were observed for the PJ8 and PJ6 strains. However, no halos of lipolytic activities were observed when the developing solution was used. Growth halos were observed for the PJ12 and PJ4 fungi, and these were the only isolated fungi that presented halos of lipolytic activity $(0.39 \mathrm{~cm}$ and $0.24 \mathrm{~cm}$, respectively) (Table 3 ).

Among the fungi already isolated in the laboratory in previous studies, the largest growth halos were observed for the 3.2TA microorganism. No halos of lipase activity were observed for the MB2.2 and P3 fungi, whereas an activity halo of $0.92 \mathrm{~cm}$ was obtained with the 3.2TA fungus, followed by fungus M1.7.1 with a halo of $0.31 \mathrm{~cm}$ (Table 3 ).

Filamentous fungi are microorganisms that stand out because of their great ease of cultivation. It is not necessary to rupture the cell for their release because they secrete their enzymes directly into the medium. In addition, they produce large amounts of enzymes, and they have a high potential for numerous industrial applications [30].

The lipases of microbial origin have a particular industrial importance and represent the most widely used class of biocatalysts in biotechnological applications. Among the microorganisms recognized as good producers of lipolytic enzymes, fungi have a great potential to be explored [31] [32] [33] [34]. The main benefit of lipases from filamentous fungi is their extracellular nature, which considerably decreases the total cost of biocatalyzed processes by these enzymes and makes them more interesting from an industrial point of view than bacterial lipases [32] [35] [36] [37]. 
Table 3. Halo (centimeters) of lipase activity produced by filamentous fungi in a solid culture medium containing Tween 80 .

\begin{tabular}{|c|c|}
\hline Fungus & Lipase halo $(\mathrm{cm})$ \\
\hline PJ1 & $-\mathrm{e}$ \\
\hline $\mathrm{PJ} 2$ & $-\mathrm{e}$ \\
\hline PJ3 & $-\mathrm{e}$ \\
\hline PJ4 & $0.24 \pm 0.02 \mathrm{~d}$ \\
\hline PJ5 & $-\mathrm{e}$ \\
\hline PJ6 & $-\mathrm{e}$ \\
\hline PJ7 & $-\mathrm{e}$ \\
\hline PJ8 & $-\mathrm{e}$ \\
\hline PF9 & $-\mathrm{e}$ \\
\hline PF10 & $-\mathrm{e}$ \\
\hline PF11 & $-\mathrm{e}$ \\
\hline PJ12 & $0.39 \pm 0.01 \mathrm{~b}$ \\
\hline P3 & $-\mathrm{e}$ \\
\hline $\mathrm{C} 435$ & $-\mathrm{e}$ \\
\hline EA3.3.2 & $-\mathrm{e}$ \\
\hline $3.2 \mathrm{TA}$ & $0.92 \pm 0.01 \mathrm{a}$ \\
\hline MB1.1 & $-\mathrm{e}$ \\
\hline EA1.2.1 & $-\mathrm{e}$ \\
\hline M1.7.1 & $0.31 \pm 0.01 \mathrm{c}$ \\
\hline MB2.2 & $-\mathrm{e}$ \\
\hline
\end{tabular}

The Tukey test was applied at the level of $5 \%$ probability. The means followed by the same letter in the column (lower case) do not differ statistically. The "-" symbol represents microorganisms that have not grown.

In this respect, filamentous fungi are widely recognized as being the best sources of lipolytic enzymes, with applications in the pharmaceutical area, in the synthesis of fine chemicals and chemical oils, in the food, leather, cosmetics, detergents, and fragrance industries, in the pretreatment of lipid-rich wastewater, in the bioremediation of soils contaminated by fats and in the synthesis of biodiesel [32] [33] [34]. In the field of biofuels, lipases have been used as catalysts for the process because of the lower energy costs and low environmental impact. Thus, it is necessary to study lipases produced by filamentous fungi for biotechnological applications.

In the work by Miranda and collaborators isolated lipase-producing microorganisms were cultivated in Marine Broth medium containing soybean oil, Tween 20, agar and the rhodamine B dye. The plates were observed under ultraviolet 
light $(365 \mathrm{~nm})$. Three microorganisms from the mangrove of Babitonga Bay were isolated, and lipase production was indicated by qualitative tests [38].

Paludo and collaborators analyzed 205 yeast strains from the Federal University of Tocantins that were isolated from decomposing leaves collected in three streams in the municipality of Taquaruçu. Lipase production was determined in medium containing peptone, $\mathrm{NaCl}, \mathrm{CaCl}_{2}$, agar and Tween-20. Of the 205 strains evaluated, positive results for at least one of the enzymes tested were observed, 83 for lipase (40.5\%), 59 for cellulase (28.8\%), 30 for xylanase (14.6\%) and 35 for amylase (17.1\%) [39].

Rodrigues and collaborators evaluated the extracellular lipolytic activity of forty-one fungal isolates in solid $\mathrm{MB}$ medium consisting of peptone, $\mathrm{NaCl}$, $\mathrm{CaCl}_{2}$, agar and Tween 80, and ten of these fungi presented activity [40].

\section{Conclusion}

The prospecting of filamentous fungi is a viable alternative that allows exploring the biotechnological potential of a given region, as it enables knowledge of the species of microorganisms that produce enzymes of biotechnological interest. From the four collection sites, it was possible to isolate nine fungi from the leaves and soil of the foot of the jabuticaba tree and three fungi from the leaves of Andu beans and their morphological characteristics such as color, size, and texture were analyzed. In analyzing the optimum growth temperature of the fungi, it was found that $95 \%$ developed at $30^{\circ} \mathrm{C}$, characterizing them as mesophilic organisms. In addition, the lipolytic potential of the 3.2TA, PJ12, M1.7.1 and PJ4 fungi was verified, an important characteristic from the biotechnological point of view.

\section{Acknowledgements}

We are grateful to the Federal University of Jequitinhonha and Mucuri Valleys, the Fundação de Amparo à Pesquisa do Estado de Minas Gerais-FAPEMIG, as well as the entire team of teachers and students who participate in the research laboratory. This project was registered in the Sistema Nacional de Gestão do Patrimônio Genético e do Conhecimento Tradicional Associado (SisGen), number A64AD93.

\section{Conflicts of Interest}

The authors declare no conflicts of interest regarding the publication of this paper.

\section{References}

[1] Pacheco, S., Cruz Jr., A., Morgado, A., Furigo Jr., A., Amadi, O., Guisán, J. and Pessela, B. (2015) Isolation and Screening of Filamentous Fungi Producing Extracellular Lipase with Potential in Biodiesel Production. Advances in Enzyme Research, 3, 101-114. https://doi.org/10.4236/aer.2015.34011

[2] Xie, W. and Huang, M. (2018) Immobilization of Candida rugosa Lipase onto Gra- 
phene Oxide $\mathrm{Fe}_{3} \mathrm{O}_{4}$ Nanocomposite: Characterization and Application for Biodiesel Production. Energy Conversion and Management, 159, 42-53. https://doi.org/10.1016/j.enconman.2018.01.021

[3] Prayogo, F.A., Budiharjo, A. and Kusumaningrum, H.P. (2020) Metagenomic Applications in Exploration and Development of Novel Enzymes from Nature: A Review. Journal of Genetic Engineering and Biotechnology, 18, Article No. 39. https://doi.org/10.1186/s43141-020-00043-9

[4] Lima, L.G.R., Gonçalves, M.M.M., Couri, S., Melo, V.F., Sant'Ana, G.C.F. and da Costa, A.C.A. (2019) D. Lipase Production by Aspergillus niger C by Submerged Fermentation. Brazilian Archives of Biology and Technology, 62. https://doi.org/10.1590/1678-4324-2019180113

[5] Marotti, B.S., Cortez, D.V., Gonçalves, D.B. and Castro, H.F.D. (2017) Seleção de espécies do gênero Penicillium produtoras de lipase ligada ao micélio para aplicação em hidrólise de óleos vegetais. Química Nova, 40, 427-435.

https://doi.org/10.21577/0100-4042.20170033

[6] Hernández-García, S., García-García, M. and García-Carmona, F. (2014) Purification, Immobilization and Characterization of Lipase Isoenzyme from Aspergillus niger with C8 Magnetic Particles. Advances in Bioscience and Biotechnology, 5, 633-641. https://doi.org/10.4236/abb.2014.57075

[7] Lehmann, S., Maraite, A., Steinhagen, M. and Ansorge-Schumacher, M. (2014) Characterization of a Novel Pseudomonas stutzeri Lipase/Esterase with Potential Application in the Production of Chiral Secondary Alcohols. Advances in Bioscience and Biotechnology, 5, 1009-1017. https://doi.org/10.4236/abb.2014.513115

[8] Imandi, S., Karanam, S. and Garapati, H. (2010) Optimization of Media Constituents for the Production of Lipase in Solid State Fermentation by Yarrowia lipolytica from palm Kernal Cake (Elaeis guineensis). Advances in Bioscience and Biotechnology, 1, 115-121. https://doi.org/10.4236/abb.2010.12016

[9] BBC Research (2018) Global Markets for Enzymes in Industrial Applications. https://www.bccresearch.com/market-research/biotechnology/global-markets-for-e nzymes-in-industrial-applications.html

[10] Cordeiro, D.O. (2019) Avaliação de catalisadores heterogêneos obtidos a partir das cascas do ovo, para síntese de biodiesel. Tese (doutorado)-Universidade Federal do Rio Grande do Norte, Centro de tecnologia, Programa de Pós-Graduação em Engenharia Química, Natal, RN.

[11] Boro, J., Deka, D. and Thakur, A. (2012) A Review On Solid Oxide Derived From Waste Shells as Catalyst For Biodiesel Production. Renewable and Sustainable Energy Reviews, 16, 904-910. https://doi.org/10.1016/j.rser.2011.09.011

[12] Geris, R., Santos, N., Amaral, B., Maia, I., Castro, V. and Carvalho, J. (2007) Biodiesel de Soja-Reação de Transesterificação para Aulas Práticas de Química Orgânica. Quimica Nova, 30, 1369-1373. https://doi.org/10.1590/S0100-40422007000500053

[13] Feng, Y., He, B., Cao, Y., Li, J., Liu, M., Yan, F. and Liang, X. (2010) Biodiesel Production Using Cation-Exchange Resin as Heterogeneous Catalyst. Bioresource Technology, 101, 1518-1521. https://doi.org/10.1016/j.biortech.2009.07.084

[14] Mutreja, V., Singh, S. and Ali, A. (2011) Biodiesel from Mutton Fat Using KOH Impregnated $\mathrm{MgO}$ as Heterogeneous Catalysts. Renewable Energy, 36, 2253-2258. https://doi.org/10.1016/j.renene.2011.01.019

[15] Zhao, L., Qiu, Z. and Stagg-Williams, S. (2013) Transesterification of Canola Oil 
Catalyzed by Nanopowder Calcium Oxide. Fuel Processing Technology, 114, 154-162. https://doi.org/10.1016/j.fuproc.2013.03.027

[16] Atadashi, I., Aroua, M., Aziz, A. and Sulaiman, N. (2011) Membrane Biodiesel Production and Refining Technology: A Critical Review. Renewable and Sustainable Energy Reviews, 15, 5051-5062. https://doi.org/10.1016/j.rser.2011.07.051

[17] Lopes, P.H.S. (2017) Produção de $\beta$-D-frutofuranosidases pelo fungo filamentoso Aspergillus sp. p4 isolado no Norte de Minas Gerais. Universidade Federal dos Vales do Jequitinhonha e Mucuri, Trabalho de Conclusão de Curso Ciência e Tecnologia, Janaúba-MG.

[18] Silva, C.H.C. (2018) Coleta, isolamento e análise termofílica de fungos filamentosos isolados no lixão da UFVJM-Campus JK. Universidade Federal dos Vales do Jequitinhonha e Mucuri, Trabalho de Conclusão de Curso Ciência e Tecnologia, Diamantina-MG.

[19] Nogueira, E.A. (2018) Análise de características de fungos filamentosos prospectados no lixão da UFVJM campus JK. Universidade Federal dos Vales do Jequitinhonha e Mucuri, Trabalho de Conclusão de Curso Ciência e Tecnologia, Diamantina-MG.

[20] Rosa, T.M.F., Marinho, B.M. and Benassi, V.M. (2017) Production of Cellulase and Sugar Fermentable Formation by the Deterioration of Sugar Cane Bagasse. Ciência e Tecnologia: FATEC-JB, Jaboticabal-SP, 9, 38-43.

[21] Oliveira, M.M.C. (2019) Isolamento de fungos filamentosos obtidos de amostras do Rio Doce e do mar coletadas em Regência, município de Linhares, estado do Espírito Santo, e padronização do cultivo do microorganismo MB 2.7 para produção de lipases. Universidade Federal dos Vales do Jequitinhonha e Mucuri, Trabalho de Conclusão de Curso Ciência e Tecnologia, Diamantina-MG.

[22] Souza, M.T.S. (2017) Prospecção de fungos filamentosos e produção de amilases por Aspergillus sp. M1.7.2. Universidade Federal dos Vales do Jequitinhonha e Mucuri, Trabalho de Conclusão de Curso Ciência e Tecnologia, Janaúba-MG.

[23] Emerson, R. (1941) An Experimental Study of the Life Cycles and Taxonomy of Allomyces. Lloydia, 4, 77-144.

[24] Domsch, K.H., Gams, W. and Anderson, T.H. (2007) Compendium of Soil Fungi. 2nd Edition, IHW-Verlag, Eching.

[25] Michelin, M. (2009) Potencial dos fungos Aspergillus terrícola e Aspergillus ochraceus no desenvolvimento de bioprocessos e propriedades das enzimas xilanolíticas $236 \mathrm{f}$. Tese (Doutorado em Ciências-Biologia Comparada)_Faculdade de Filosofia, Ciências e Letras de Ribeirão Preto, Universidade de São Paulo, Ribeirão Preto.

[26] Zipperer, M., Minotto, E., Gelinski, J.M.L.N., Barato, C.M. and Geremias, R. (2010) Isolamento e seleção de fungos de solo de cultivo de videiras contaminado com dicarbamato para biorremediação. Anuário pesquisa e extensão UNOESC Videira.

[27] Souza, M.T.S., Marinho, B.M., Pasin, T.M., Nelson, D.L. and Benassi, V.M. (2020) Prospection of Filamentous Fungi and the Production of Amylase by Aspergillus sp. M1.7.2. The Journal of Engineering and Exact Sciences, 6, 365-376. https://doi.org/10.18540/jcecvl6iss3pp0365-0376

[28] Pelczar, M.J., Chan, E.C.S. and Krieg, N.R. (1997) Microbiologia: Conceitos e Aplicações, Vol. 1. 2nd Edition, MAKRON Books, São Paulo.

[29] Santos, A.M.A., Marinho, B.M. and Benassi, V.M. (2019) Produção de celulases por fungos filamentosos isolados no Norte de Minas Gerais cultivados em meio de cultura contendo resíduos de bananeira. Atena Editora, cap.8.

https://doi.org/10.22533/at.ed.7911925048 
[30] Nascimento, K.B.M., Martins, A.G.R., Takaki, G.M.C., Silva, C.A.A. and Okada, K. (2014) Utilização de resíduos agroindustriais para produção de tanase por Aspergillus $s p$ isolado do solo da caatinga de Pernambuco, Brasil. Revista E-Xacta, 7, 95-103. https://doi.org/10.18674/exacta.v7i1.1146

[31] Bharathi, D. and Rajalakshmi, G. (2019) Microbial Lipases: An Overview of Screening, Production and Purification. Biocatalysis and Agricultural Biotechnology, 22, 101368. https://doi.org/10.1016/j.bcab.2019.101368

[32] Melani, N.B., Tambourgi, E.B. and Silveira, E. (2019) Lipases: From Production to Applications. Separation \& Purification Reviews, 49, 1-16.

[33] Javed, S., Azeem, F., Hussain, S., Rasul, I., Siddique, M.H., Riaz, M. and Nadeem, H. (2018) Bacterial Lipases: A Review on Purification and Characterization. Progress in Biophysics and Molecular Biology, 132, 23-34. https://doi.org/10.1016/j.pbiomolbio.2017.07.014

[34] Priji, P., Sajith, S., Faisal, P.A. and Benjamin, S. (2016) Microbial Lipases-Properties and Applications. The Journal of Microbiology, Biotechnology and Food Sciences, 6, 794-798. https://doi.org/10.15414/jmbfs.2016.6.2.799-807

[35] Zavarise, J.P. and Pinotti, L.M. (2019) Progress in the Production of Fungal Lipases by Submerged Fermentation. International Journal of Advanced Engineering Research and Science, 6, 367-373. https://doi.org/10.22161/ijaers.612.38

[36] Kumar, A., Dhar, K., Kanwar, S.S. and Arora, P.K. (2016) Lipase Catalysis in Organic Solvents: Advantages and Applications. Biological Procedures Online, 18, Article No. 2. https://doi.org/10.1186/s12575-016-0033-2

[37] Treichel, H., Oliveira, D., Mazutti, M.A., Di Luccio, M. and Oliveira, J.V. (2010). A Review on Microbial Lipases Production. Food and Bioprocess Technology, 3, 182-196. https://doi.org/10.1007/s11947-009-0202-2

[38] Miranda, M.L.P., Ortman, M.S., Schneide, A.L.S., Wisbeck, E. and Gern, R.M.M. (2019) Evaluation of Lipase and Biosurfactant Production by Microorganisms Isolated from Mangrove Sediments of Baía Babitonga in Santa Catarina. Brazil Revista NBC-Belo Horizonte, 9, No. 18.

[39] Paludo, G.B., Lima, T.L.A. and Carreiro, S.C. (2018) Potencial enzimático de leveduras isoladas de folhas em decomposição. Acta Tecnológica, 13, No. 2. https://doi.org/10.35818/acta.v13i2.666

[40] Rodrigues, C., Cassini, S.T., Antunes, P.W., Keller, R.P. and Gonçalves, R.F. (2016) Isolation and Selection of Lipase-Producing Fungi Based on Lipase Activity and Hydrolytic Potential on Soybean Oil and Grease Trap Scum. Engenharia Sanitaria e Ambiental, 21, No. 3. https://doi.org/10.1590/S1413-41522016141401 